\title{
Effect of Biofertilizers and Split Application of Vermicompost on Productivity and Profitability of Wheat (Triticum aestivum L.) Crop in Clay Loam Soils
}

\author{
Sushila Aechra*, R. H. Meena, Gajanand Jat, Jitendra Sharma, \\ Kiran Doodhwal and Hemraj Jat \\ Department of Soil Science and Agricultural Chemistry, Maharana Pratap University of \\ Agriculture and Technology, Udaipur, Rajasthan, India \\ *Corresponding author
}

A B S T R A C T

K e y w o r d s
Biofertilizers,
Vermicompost,
Yield, Wheat, Split
application

A field experiment was conducted for two consecutive rabi (winter) seasons during 2017-18 and 2018-19 at the Instructional Farm of RCA, Udaipur, Rajasthan to study the effect of biofertilizers and split application of vermicompost on productivity and profitability of wheat (Triticum aestiuvm. L.). Two years pooled data indicate that growth attributes (plant height), yield attributing traits (total tillers, effective tillers and test weight), yields viz., grain, straw and biological in wheat differ significantly in both biofertilizers and vermicompost treatments and were maximum with the $\mathrm{B}_{5}$ (Azotobacter $+\mathrm{PSB}+\mathrm{KMB}+\mathrm{ZnSB})$ and $\mathrm{V}_{3}(50 \%$ at sowing $+50 \%$ at tillering) as compared to control. The highest net return and $\mathrm{B}: \mathrm{C}$ ratio was obtained with $\mathrm{B}_{5}($ Azotobacter $+\mathrm{PSB}+\mathrm{KMB}+\mathrm{ZnSB})$ and vermicompost with $\mathrm{V}_{3}(50 \%$ at sowing $+50 \%$ at tillering) of wheat. Interaction effect of biofertilizers and vermicompost on yield and economy of wheat were found significant.

\section{Introduction}

Wheat is the most important cereal crop of the family Poaceae. Wheat is the second most important food grain crop in India ranking next to rice contributing about $35 \%$ of the food grain production in India. The rising population and reduction in available land and other productive units are placing unprecedented pressure on the current agriculture and natural resources to meet the increasing food demand. Adoption of intensive system will meet the food demand of growing population. The manufacturing of synthetic fertilizers is highly cost effective and depended on non-renewable fossils fuel that is in acute shortage. Eff orts have been devoted to reduce chemical fertilizers 
application in wheat production, organic manure and biofertilizers amendments are considered to be feasible ways to realize this goal without decreasing grain yields (Urib et al., 2010).

Indigenous sources like FYM, vermicompost and biofertilizers should be encourage as it supply plant nutrient, improve the soil biodiversity and thereby increase the productivity and fertility of the soil.

Bio-fertilizers being essential components of organic farming play vital role in maintaining long term soil fertility and sustainability by fixing atmospheric nitrogen. Keep the soil environment rich in all kinds of micro- and macro-nutrients via nitrogen fixation, phosphate and potassium solubalization or mineralization, release of plant growth regulating substances, production of antibiotics and biodegradation of organic matter in the soil (Sinha et al., 2014).

It is evident the biofertilizers like Azotobacter in combination have great prospect for increasing productivity of wheat. When seeds are inoculated with biofertilizers, they multiply and participate in nutrient cycling and improved crop productivity (Singh et al., 2011).

Vermicompost is the microbial composting of organic wastes through earthworm activity to form organic fertilizers which contain higher level of organic matter, organic carbon, total and available $\mathrm{N}, \mathrm{P}, \mathrm{K}$ and micronutrients, microbial and enzyme activities (Parthasarathi et al., 2007).

Split application of vermicompost resulted in higher yield parameters such as panicles, filled grains per panicle and total spikelets per panicle, grain yield and NUE in rice but only if vermicompost was applied at two or three doses (Bejbaruah et al., 2013). The objective behind this experimentation was to increase the yield attributes and yield of wheat along with use of biofertilizers and vermicompost.

\section{Materials and Methods}

\section{Experimental Location and Design}

A field experiment was laid at Instructional Farm, Rajasthan College of Agriculture, Udaipur. The site is situated at $24^{\circ} .35^{\prime}$ North Latitude and $74^{\circ} .42^{\prime}$ East Longitude with the altitude of $579.5 \mathrm{~m}$ above mean sea level. The region comes under agro-climatic zone IVA (Sub-Humid Southern Plain and Aravalli Hills) of Rajasthan. The wheat crop experienced maximum and minimum temperature ranged between 23.43 to 37.85 ${ }^{\circ} \mathrm{C}$ and 5.21 to $19.83^{\circ} \mathrm{C}$ during rabi $2017-18$, respectively.

The corresponding temperature fluctuations during second year (2018- 19) of experimentation were 21.58 to $39.40{ }^{\circ} \mathrm{C}$ and 4.07 to $20.10{ }^{\circ} \mathrm{C}$, respectively. Total rainfall received during the crop season was $6.60 \mathrm{~mm}$ during 2017-18 and $1.9 \mathrm{~mm}$ in 2018-19, respectively. The weather data during experimental period was collected from the meteorological observatory of agronomy. The soil is an vertisols with a clay loam texture (sand $38.57 \%$, silt $26.66 \%$ and clay $34.37 \%$ ) neutral alkaline in reaction, medium in available nitrogen (251 $\left.\mathrm{kg} \mathrm{ha}{ }^{-1}\right)$ and phosphorus $\left(18 \mathrm{~kg} \mathrm{ha}^{-1}\right)$ and high in available potassium (443 $\left.\mathrm{kg} \mathrm{ha}^{-1}\right)$.

To ascertain physico-chemical characteristics of the experimental field, soil samples up to $0-15 \mathrm{~cm}$ depth were drawn from different spots of field and a representative composite sample was prepared by mixing and phiscochemical and biological analysis using standard methods. The study was designated with different biofertilizers and vermicompost treatments. 
We selected five levels of biofertilizers [Control $\left(\mathrm{B}_{1}\right)$, Azotobacter $\left(\mathrm{B}_{2}\right)$, Azotobacter $+\mathrm{PSB}\left(\mathrm{B}_{3}\right)$, Azotobacter+ $\mathrm{PSB}+\mathrm{KMB}\left(\mathrm{B}_{4}\right)$ and Azotobacter+PSB+ $\left.\mathrm{KMB}+\mathrm{ZnSB}\left(\mathrm{B}_{5}\right)\right]$ and four levels of vermicompost [Control $\left(\mathrm{V}_{1}\right), 100 \%$ at sowing $\left(\mathrm{V}_{2}\right), 50 \%$ at sowing $+50 \%$ at tillering $\left(\mathrm{V}_{3}\right)$ and $50 \%$ at sowing $+50 \%$ at tillering $\left.\left(\mathrm{V}_{4}\right)\right]$, making twenty treatment combinations. These treatments were replicated thrice in Factorial Randomized Block Design.

\section{Treatment application and crop management}

The experiment field was disposed of for two years to confirm the same soil properties. After harvesting of Kharif season crop, the experimental field was prepared by ploughing $(0-15 \mathrm{~cm})$ with tractor drawn disc plough followed by cross harrowing and planking to bring the soil in to good tilth. Before sowing, all the biofertilizers viz. Azotobacter, PSB, $\mathrm{KMB}$ and $\mathrm{Zn}$ solublizer will be used as seed treatment@ $5 \mathrm{ml} \mathrm{kg}^{-1}$ of each biofertilizers. The application of vermicompost @ $4 \mathrm{tha}^{-1}$ will be applied in the field as per treatments mixed at the time of sowing and tillering stage.

The details nutrient content present in the vermicompost is given in Table 1 . Necessary intercultural operations were regularly monitored for maintaining optimum plant growth condition.

The crop was intermitted irrigation, crop weeded were done at 30 and 45 days after sowing, respectively for weed control in the wheat crop, use of pesticides for pest control were carried out following the farmers practices.

Crop was manually harvested, after the crop harvested, the straw and yield were air dried and weight. Soil samples from the top soil (0-
$15 \mathrm{~cm}$ ) were taken at four different points of each replicated plots were thoroughly mixed to make homogeneous composite sample of each replication, air dried and transferred in clean polythene bags.

\section{Plant sampling and analysis}

Plant samples were taken from each plot for the recorded the observation and analysis. Plant height at harvest should be measured randomly with the help of scale meter, total number of tillers at 60 DAS and number of effective tillers (ear bearing tillers) at physiological maturity were recorded nondestructively from two randomly selected one meter row length in each plot.

The total biomass harvested from each net plot was threshed; winnowed, cleaned and dried grains of wheat thus obtained were weighed in terms of $\mathrm{kg} \mathrm{plot}^{-1}$. Straw yield of wheat was calculated by subtracting grain yield from respective biological yield of each treatment and expressed in terms of $\mathrm{kg} \mathrm{ha}^{-1}$.

The ratio of economic yield (grain yield) to biological yield was worked out to estimate harvest index and expressed as percentage as suggested by Donald and Hablin (1976). For the test weight 1000 grains were counted and weighed and expressed in gram.

\section{Statistical analysis}

All the recorded data were subjected to statistical analysis using analysis of variance (ANOVA) techniques as applicable to random block design. The two years plant data is presented so after carrying out F- test of homogeneity of variance, the yield data from two years were pooled and statistically analyzed and least significant difference (LSD) at $\mathrm{P}=0.05$ was used to test the differences between means of individual treatments (Gomez and Gomez, 1984). 


\section{Results and Discussion}

\section{Growth}

Plant height pertaining to different biofertilizres recorded at harvest has been presented in table 2 .

\section{Effect of biofertilizers}

Among the treatments, $\mathrm{B}_{5}$ (Azotobacter+ $\mathrm{PSB}+\mathrm{KMB}+\mathrm{ZnSB}$ ) had maximum plant height $(101.99 \mathrm{~cm})$ at harvest of wheat, which was significantly higher than $\mathrm{B}_{3}$ (Azotobacter + PSB), $\mathrm{B}_{2}$ (Azotobacter) and $\mathrm{B}_{1}$ (control). But it was at par with $\mathrm{B}_{4}$ (Azotobacter + PSB $+\mathrm{KMB})$. The variation in plant height due to nutrient sources was considered to be the variation in nutrient availability.

Biofertilizers improve growth by increasing the supply or availability of primary nutrients to the host plant. The increased endogenous nitrogen content due to inoculation might have promoted crop growth. These results were supported by Ahemad and Khan, (2009) and Kaushik et al., (2012).

\section{Effect of vermicompost}

Data (Table 2) revealed that among the treatments, $\quad \mathrm{V}_{3} \quad(50 \%$ at sowing $+50 \%$ at tillering) had maximum plant height (101.58 $\mathrm{cm})$ at harvest of wheat, which was significantly higher than $V_{2}(100 \%$ at sowing) and $\mathrm{V}_{1}$ (control). But it was at par with $\mathrm{V}_{4}$ $(75 \%$ at sowing $+25 \%$ at tillering). This clearly indicates that higher level of nutrients helped in the elongation of stem due to development of cells, rapid cell division and cell elongation in meristematic region of plant. The similar results noted by Kheyri et al., (2017).

\section{Yield attributes and yield}

The data regarding yield of wheat were summarised in Table 2 and revealed that the grain and straw yield of wheat were also positively affected by seed inoculation with biofertilizers and spilt application of vermicompost.

\section{Effect of biofertilizers}

Biofertilizers had a remarkable influenced on the total number of tillers, effective number of tillers, test weight, grain yield, straw yield, biological yield of wheat. Data (Table 2 and 3) recorded that treatment $\mathrm{B}_{5}$ (Azotobacter+ $\mathrm{PSB}+\mathrm{KMB}+\mathrm{ZnSB}$ ) had maximum number of total tillers (91.71) and effective tillers (77.88) per meter row length at harvest of wheat, which was significantly higher than $\mathrm{B}_{3}$ (Azotobacter $+\mathrm{PSB}), \mathrm{B}_{2}$ (Azotobacter) and $\mathrm{B}_{1}$ (control) except $\mathrm{B}_{4} \quad$ (Azotobacter $+\mathrm{PSB}+$ $\mathrm{KMB})$.

Application of different biofertilizers has significantly affected grain yield, straw yield and biological yield of wheat over the control and single inoculation (Table 3). Treatment $\mathrm{B}_{5} \quad$ (Azotobacter $\left.+\mathrm{PSB}+\mathrm{KMB}+\mathrm{ZnSB}\right)$ had higher grain yield $\left(4564.75 \mathrm{~kg} \mathrm{ha}^{-1}\right)$, straw yield $\left(6606.7 \mathrm{~kg} \mathrm{ha}^{-1}\right)$ and biological yield $\left(11171.42 \mathrm{~kg} \mathrm{ha}^{-1}\right)$ at harvest of wheat, which was significantly higher than $\mathrm{B}_{3}$ (Azotobacter $+\mathrm{PSB}), \mathrm{B}_{2}$ (Azotobacter) and $\mathrm{B}_{1}$ (control), But it was at par with $\mathrm{B}_{4}$ (Azotobacter+PSB+KMB).

Highest test weight (44.45 g) was recorded with $\mathrm{B}_{5}$ (Azotobacter $\left.+\mathrm{PSB}+\mathrm{KMB}+\mathrm{ZnSB}\right)$, which was at par with $B_{4}$. Treatments $B_{4}, B_{3}$ remained at par with each other. Increase in yield attributes and yield of wheat with biofertilizers seems owing to increased supply of plant hormones by the microorganisms or by roots as results of reaction to microbial colonization (Avivi and Feldman, 1982). Priming with biofertiliser inoculations significantly improves grain yield, straw yield and biological yield of wheat crop Patra and Singh (2018). Harvest index of wheat was not influenced significantly with the application 
of biofertilizers. This might be due to variable rate of translocation of assimilate toward grain development, leading to variability in yield and HI value among the applied treatments (Kumawat et al., 2017).

\section{Effect of vermicompost}

Vermicompost contains primary, secondary and micronutrients. Thus, significantly influence total number of tillers, effective number of tillers, test weight, grain yield, straw yield, biological yield of wheat. Tillering is an important trait for grain production, application of vermicompost has significantly influence total tillers and effective tillers of wheat (Table 2). Treatment $\mathrm{V}_{3} \quad(50 \%$ at sowing $+50 \%$ at tillering) had maximum number of total tillers (92.29) and effective tillers (76.79) per meter row length at harvest of wheat, which was significantly higher than $\mathrm{V}_{2}\left(50 \%\right.$ at sowing) and $\mathrm{V}_{1}$ (control).

But it was at par with $\mathrm{V}_{4} \quad(75 \%$ at sowing $+25 \%$ at tillering). Application of vermicompost has significantly affected grain yield, straw yield and biological yield of wheat over the control (Table 3). Treatment $\mathrm{V}_{3} \quad(50 \%$ at sowing+50\%at tillering) had higher grain yield $\left(4587.25 \mathrm{~kg} \mathrm{ha}^{-1}\right)$, straw yield $\left(6648.5 \mathrm{~kg} \mathrm{ha}^{-1}\right)$ and biological yield $\left(11235.54 \mathrm{~kg} \mathrm{ha}^{-1}\right)$ at harvest of wheat, which was significantly higher than $\mathrm{V}_{2}(100 \%$ at sowing) and $\mathrm{V}_{1}$ (control) however, it was at par with $\mathrm{V}_{4}$ ( $75 \%$ at sowing+25\%at tillering). Highest test weight (43.73 g) was recorded with $\mathrm{V}_{3}$ (Azotobacter $\left.+\mathrm{PSB}+\mathrm{KMB}+\mathrm{ZnSB}\right)$, which was at par with $\mathrm{V}_{4}$. Harvest index of wheat was not influenced significantly with the split application of vermicompost.

The beneficial effect of vermicompost split doses on these parameters might also be due to its continuous contribution in supplying addition plant nutrients and increasing the availability of native soil nutrients. It seems that if vermicomposting is applied in three splits, it can boost plant growth and consequently increase grain yield (Kheyri, 2017).

The increase in yield attributes with the application of vermicompost might be due to higher availability of balanced plant nutrients throughout the crop period especially at critical stages of plant (Surendra Rao and Sitaramaya, 2000). Vermicompost applied at 2, 4 and $6 \mathrm{t} \mathrm{ha}^{-1}$ increased grains yield of wheat by 11,17 and $26 \%$ over control respectively (Hadis et al., 2018).

Similar finding of harvest index also reported by (Biri et al., 2016) this might be due to competition for growth resources, i.e. moisture, nutrients and light. These all had played great roles in enhancing the biological, grain and straw yields, in the present experimentation. The similar results noted by Khan et al., (2013).

\section{Economics}

The data concerned with economics of wheat were summarized in Table 4. It is envisaged with the figure that cost of cultivation in rupees per hectare. Economics of production is very important aspect to adjudge the efficiency of different production systems based on physical feasibility and its commercial viability, while calculating the economics viz; cost of cultivation, gross income, net income and $\mathrm{B}: \mathrm{C}$ ratio were into consideration. The gross income was influenced significantly by the application of different biofertilizers and vermicompost treatments.

\section{Effect of biofertilizers}

Data presented in Table 4 and reported that treatment $\quad \mathrm{B}_{5} \quad$ (Azotobacter+PSB+KMB+ 
ZnSB) had higher gross return (Rs 99979.1 $\mathrm{ha}^{-1}$ ), net return (Rs 67529.1 ha ${ }^{-1}$ ) and BC ratio (1.50) of wheat, which was significantly higher than $\mathrm{B}_{3}$ (Azotobacter+PSB), $\mathrm{B}_{2}$ (Azotobacter) and $\mathrm{B}_{1}$ (control), But it was at par with $\mathrm{B}_{4}$ (Azotobacter $\left.+\mathrm{PSB}+\mathrm{KMB}\right)$. Use of efficient strains of bio-fertilizers are environment friendly, low cost agricultural inputs that have an important role in improving nutrient supply to crops but also reducing the cost of production (Kumar, 2013).

\section{Effect of vermicompost}

Data (Table 4) revealed that treatment $\mathrm{V}_{3}$ (50\% at sowing $+50 \%$ at tillering) had higher gross return (Rs $100501.5 \mathrm{ha}^{-1}$ ), net return (Rs $67451.5 \mathrm{ha}^{-1}$ ) and BC ratio (2.04) of wheat, which was significantly higher than $\mathrm{V}_{2}(100 \%$ at sowing) and $\mathrm{V}_{1}$ (control), But it was at par with $\mathrm{V}_{4}(75 \%$ at sowing $+25 \%$ at tillering). These finding also supported by Verma et al., (2014).

Table.1 Chemical characteristics of vermicompost applied in experiment

\begin{tabular}{|c|c|c|c|}
\hline Nutrient content & $\mathbf{N}(\boldsymbol{\%})$ & $\mathbf{P}(\boldsymbol{\%})$ & $\mathbf{K}(\boldsymbol{\%})$ \\
\hline $\mathbf{2 0 1 7 - 1 8}$ & 1.14 & 0.79 & 0.71 \\
\hline $\mathbf{2 0 1 8 - 1 9}$ & 1.16 & 0.76 & 0.69 \\
\hline
\end{tabular}

Table.2 Effect of biofertilizers and vermicompost on growth and yield attributes of wheat (Pooled means data)

\begin{tabular}{|c|c|c|c|c|}
\hline Treatments & $\begin{array}{l}\text { Plant height } \\
\text { (cm) }\end{array}$ & $\begin{array}{c}\text { Total tillers } \\
\text { m }^{-1} \text { row length }\end{array}$ & $\begin{array}{c}\text { Effective } \\
\text { tillers } \mathbf{m}^{-1} \text { row } \\
\text { length }\end{array}$ & $\begin{array}{c}\text { Test } \\
\text { weight }(g)\end{array}$ \\
\hline \multicolumn{5}{|l|}{ Biofertilizers } \\
\hline$B_{1}$ (control) & 85.95 & 74.97 & 59.99 & 38.73 \\
\hline $\mathbf{B}_{2}$ (Azotobacter) & 91.79 & 84.32 & 66.68 & 41.12 \\
\hline $\mathrm{B}_{3}($ Azot.+PSB $)$ & 96.33 & 88.03 & 73.54 & 42.77 \\
\hline $\mathrm{B}_{4}($ Azot.+PSB+KMB $)$ & 100.92 & 89.47 & 75.84 & 43.52 \\
\hline $\mathrm{B}_{5}(\mathrm{Azot} .+\mathrm{PSB}+\mathrm{KMB}+\mathrm{ZnSB})$ & 101.99 & 91.71 & 77.88 & 44.45 \\
\hline SEm \pm & 0.99 & 0.91 & 0.91 & 0.41 \\
\hline C.D. $(P=0.05)$ & 2.81 & 2.58 & 2.58 & 1.16 \\
\hline \multicolumn{5}{|l|}{ Vermicompost } \\
\hline$V_{1}$ (Control) & 84.82 & 75.47 & 60.95 & 39.06 \\
\hline $\mathrm{V}_{2}(100 \%$ at sowing $)$ & 95.36 & 83.32 & 68.82 & 42.07 \\
\hline $\begin{array}{l}V_{3}(\mathbf{5 0 \%} \text { at sowing }+50 \% \text { at } \\
\text { tillering) }\end{array}$ & 101.58 & 92.29 & 76.79 & 43.73 \\
\hline $\begin{array}{l}V_{4}(75 \% \text { at sowing }+25 \% \text { at } \\
\text { tillering) }\end{array}$ & 99.83 & 90.13 & 76.58 & 43.61 \\
\hline SEm \pm & 0.88 & 0.81 & 0.81 & 0.36 \\
\hline C.D. $(P=0.05)$ & 2.51 & 2.31 & 2.31 & 1.03 \\
\hline
\end{tabular}


Table.3 Effect of biofertilizers and vermicompost on yield (grain, straw and biological) and harvest index of wheat (Pooled data)

\begin{tabular}{|c|c|c|c|c|}
\hline Treatments & $\begin{array}{l}\text { Grain yield } \\
\left(\mathrm{kg} \mathrm{ha}^{-1}\right)\end{array}$ & $\begin{array}{l}\text { Straw yield } \\
\left(\mathrm{kg} \mathrm{ha}^{-1}\right)\end{array}$ & $\begin{array}{l}\text { Biological yield } \\
\left(\mathrm{kg} \mathrm{ha}^{-1}\right)\end{array}$ & $\begin{array}{l}\text { Harvest index } \\
(\%)\end{array}$ \\
\hline \multicolumn{5}{|l|}{ Biofertilizers } \\
\hline$B_{1}($ control $)$ & 3611.19 & 5304.7 & 8915.88 & 40.44 \\
\hline $\mathbf{B}_{2}$ (Azotobacter) & 3949.16 & 5713.1 & 9637.30 & 41.02 \\
\hline B $_{3}$ (Azot.+PSB) & 4285.47 & 6223.3 & 10508.78 & 40.43 \\
\hline $\mathrm{B}_{4}($ Azot.+PSB+KMB $)$ & 4479.24 & 6543.5 & 11047.71 & 40.91 \\
\hline $\mathrm{B}_{5}($ Azot.+PSB+KMB+ZnSB $)$ & 4564.75 & 6606.7 & 11171.42 & 40.82 \\
\hline SEm \pm & 33.73 & 49.5 & 70.840 & 0.243 \\
\hline C.D. $(P=0.05)$ & 95.55 & 140.2 & 200.691 & NS \\
\hline \multicolumn{5}{|l|}{ Vermicompost } \\
\hline $\mathrm{V}_{1}($ Control $)$ & 3631.03 & 5329.0 & 8960.03 & 40.51 \\
\hline$V_{2}(100 \%$ at sowing $)$ & 3969.92 & 5797.2 & 9767.09 & 40.66 \\
\hline $\begin{array}{l}\mathrm{V}_{3}(\mathbf{5 0 \%} \text { at sowing }+50 \% \text { at } \\
\text { tillering) }\end{array}$ & 4587.25 & 6648.5 & 11235.74 & 40.84 \\
\hline $\begin{array}{l}\mathrm{V}_{4}(75 \% \text { at sowing }+25 \% \text { at } \\
\text { tillering) }\end{array}$ & 4523.67 & 6538.3 & 11062.01 & 40.88 \\
\hline SEm \pm & 30.17 & 44.3 & 63.362 & 0.217 \\
\hline C.D. $(P=0.05)$ & 85.46 & 125.4 & 179.504 & NS \\
\hline
\end{tabular}

Table.4 Effect of biofertilizers and vermicompost on gross, net return and BC ratio of wheat (pooled data)

\begin{tabular}{|c|c|c|c|}
\hline Treatments & $\begin{array}{l}\text { Gross return } \\
\left(\text { Rs ha }^{-1}\right)\end{array}$ & $\begin{array}{l}\text { Net return } \\
\left(\text { Rs ha }^{-1}\right)\end{array}$ & BC ratio \\
\hline \multicolumn{4}{|l|}{ Biofertilizers } \\
\hline $\mathbf{B}_{1}$ (control) & 79312.1 & 47662.1 & 1.50 \\
\hline $\mathbf{B}_{2}$ (Azotobacter) & 86421.0 & 54571.0 & 1.71 \\
\hline B $_{3}$ (Azot.+PSB) & 94199.1 & 62149.1 & 1.94 \\
\hline $\mathrm{B}_{4}(\mathrm{Azot} .+\mathrm{PSB}+\mathrm{KMB})$ & 98068.7 & 65818.7 & 2.04 \\
\hline $\mathrm{B}_{5}(\mathrm{Azot}+\mathrm{PSB}+\mathrm{KMB}+\mathrm{ZnSB})$ & 99979.1 & 67529.1 & 2.08 \\
\hline SEm \pm & 650.6 & 652.6 & 0.02 \\
\hline C.D. at 0.05 & 1843.1 & 1823.9 & 0.06 \\
\hline \multicolumn{4}{|l|}{ Vermicompost } \\
\hline$V_{1}($ Control) & 79734.6 & 50684.6 & 1.74 \\
\hline$V_{2}(100 \%$ at sowing $)$ & 87095.0 & 54045.0 & 1.63 \\
\hline$V_{3}(50 \%$ at sowing $+50 \%$ at tillering $)$ & 100501.5 & 67451.5 & 2.04 \\
\hline$V_{4}(75 \%$ at sowing $+25 \%$ at tillering) & 99052.7 & 66002.7 & 2.00 \\
\hline SEm \pm & 581.9 & 585.3 & 0.02 \\
\hline C.D. at 0.05 & 1648.6 & 1618.4 & 0.05 \\
\hline
\end{tabular}




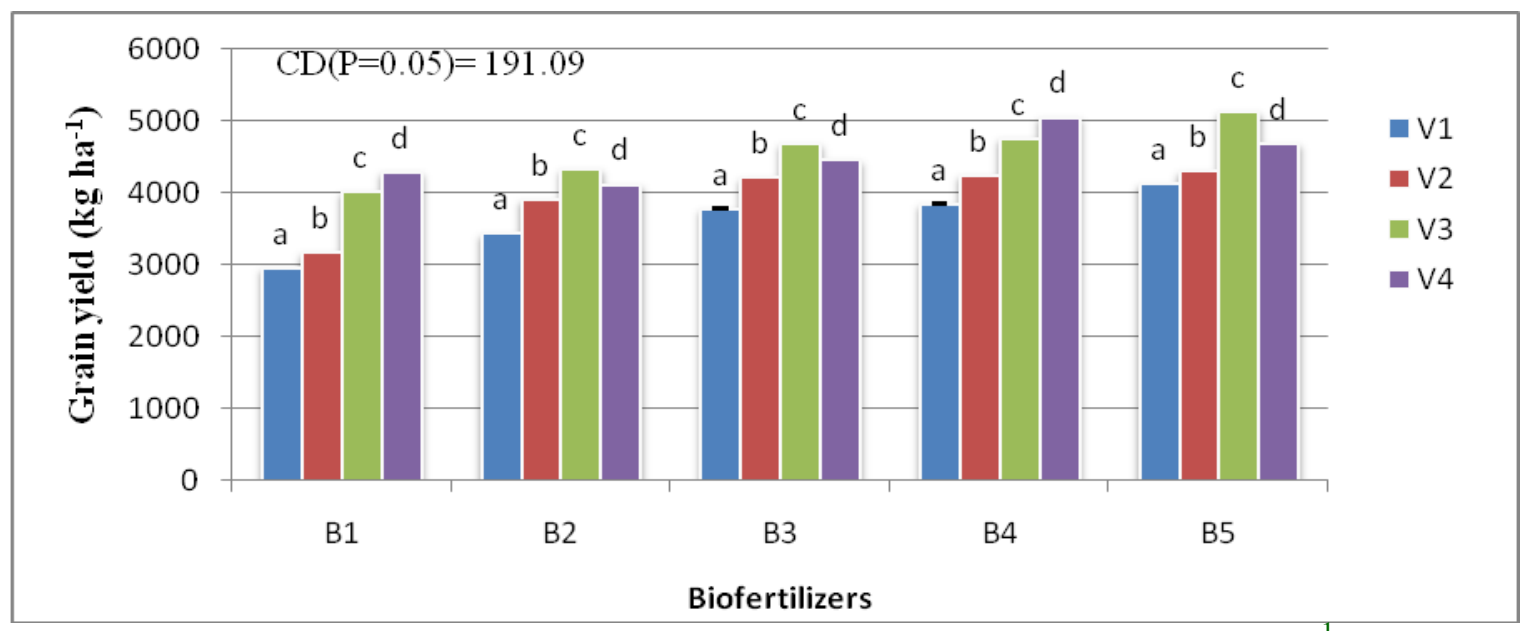

Fig.1 Interactive effect of biofertilizers and vermicompost on grain yield $\left(\mathrm{kg} \mathrm{ha}^{-1}\right)$ of wheat in pooled basis. The error bars shows the $\operatorname{LSD}(\mathrm{p}=0.05)$ values

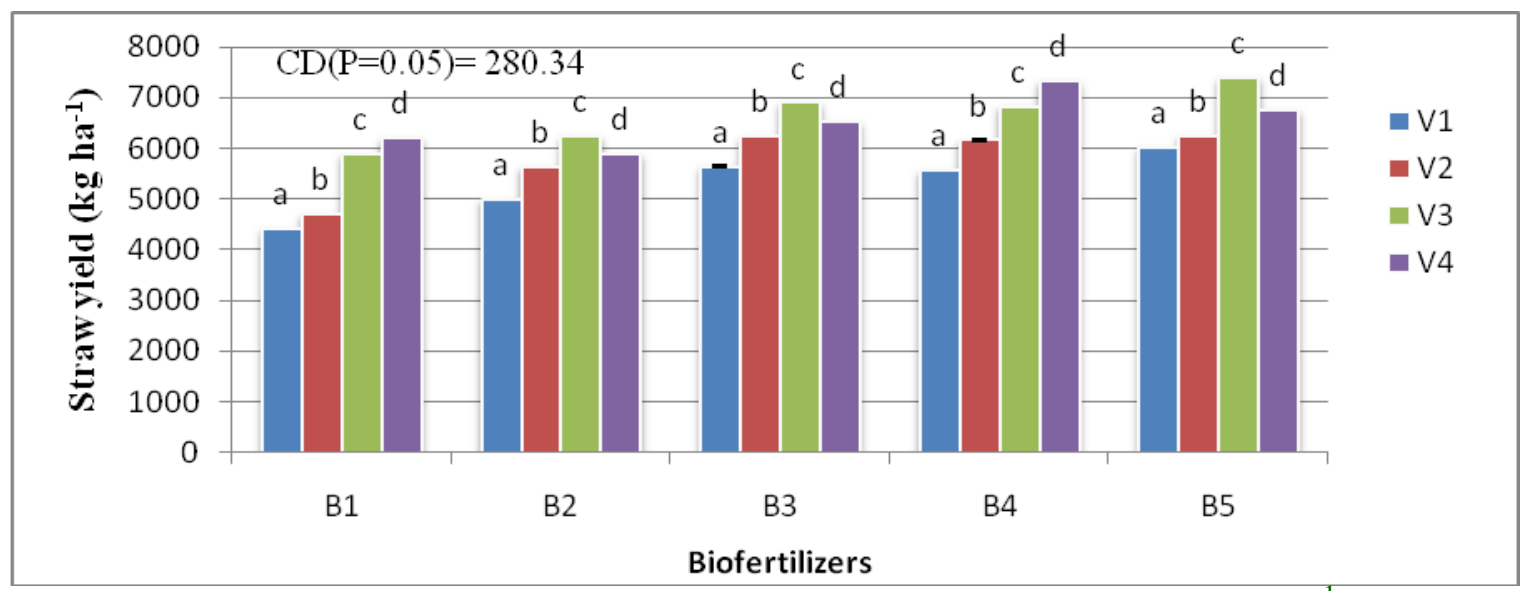

Fig.2 Interactive effect of biofertilizers and vermicompost on straw yield $\left(\mathrm{kg} \mathrm{ha}^{-1}\right)$ of wheat in pooled basis. The error bars shows the $\operatorname{LSD}(\mathrm{p}=0.05)$ values

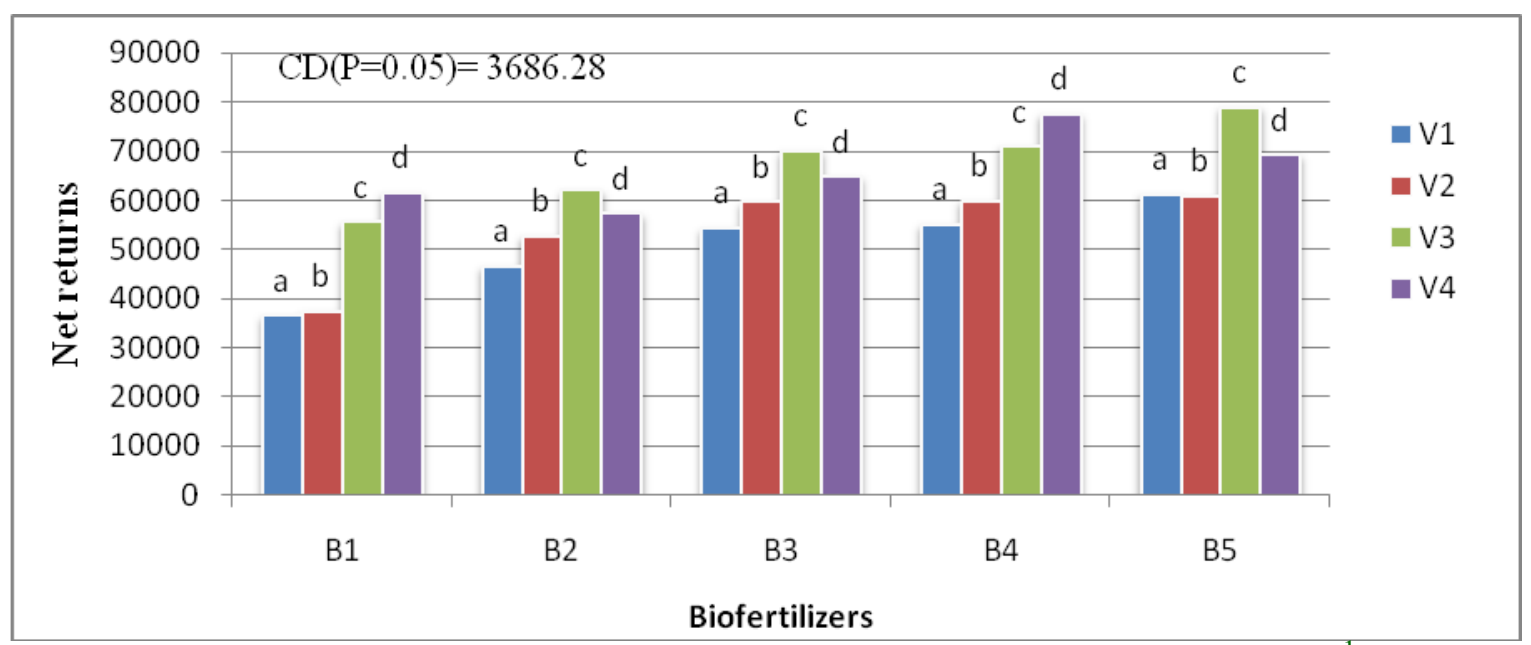

Fig. 3 Interactive effect of biofertilizers and vermicompost on net returns $\left(\mathrm{Rs} \mathrm{ha}^{-1}\right)$ in pooled basis. The error bars shows the $\operatorname{LSD}(\mathrm{p}=0.05)$ values 


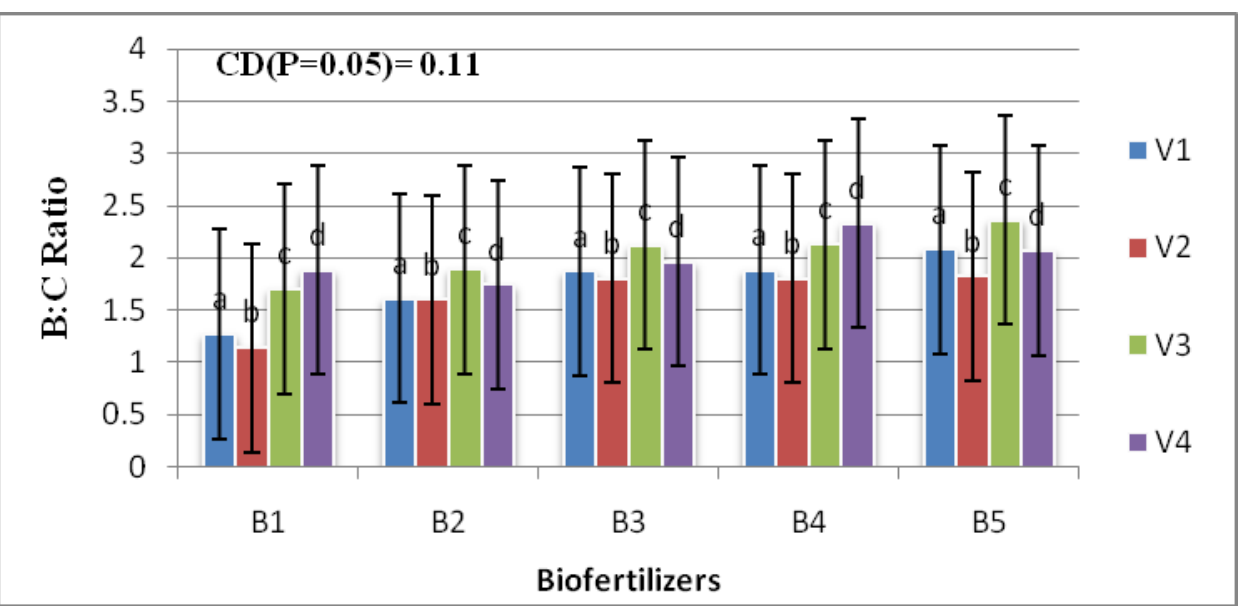

Fig.4 Interactive effect of biofertilizers and vermicompost on $\mathrm{B}: \mathrm{C}$ ratio of wheat in pooled basis.

The error bars shows the LSD $(p=0.05)$ values

Interaction effect of biofertilizer and vermicompost on yield and economics

Interaction effect of biofertilizers and vermicompost on grain yield and straw yield was significant (Fig. 1 and 2). Results showed that the highest grain yield and straw yield (5132.56 kg ha ${ }^{-1}$ and $7396.02 \mathrm{~kg} \mathrm{ha}^{-1}$ ) was recorded from $\mathrm{B}_{5} \mathrm{~V}_{3}$ treatment, which was at par $\mathrm{B}_{4} \mathrm{~V}_{4}$. On the other hand, the lowest grain and straw yield $\left(2956.58 \mathrm{~kg} \mathrm{ha}^{-1}\right.$ and 4419.24 $\mathrm{kg} \mathrm{ha}{ }^{-1}$ ) was recorded from $\mathrm{B}_{1} \mathrm{~V}_{1}$ treatment. Similar results were recorded by Azarpour et al., (2012) and Arancon and Edwards (2005). Further revealed that (Fig. 3 and 4) Comparison of mean between interaction effect levels of biofertilizers and vermicompost showed that, the highest net return and $\mathrm{BC}$ ratio ( $\mathrm{Rs} 78884.23 \mathrm{ha}^{-1}$ and 2.33) was recorded from $B_{5} V_{5}$ treatment which was at par $\mathrm{B}_{4} \mathrm{~V}_{4}$, respectively. Similar findings also reported by Sharma et al., (2009).

Based on the finding of the present investigation, it can be referred that application of bifertilizers along with vermicompost proved in significance on growth dynamics, productivity of wheat. From the present study it was observed that biofertilizers (Azotobacter + PSB + KMB +
$\mathrm{ZnSB})+$ vermicompost as $(50 \%$ at sowing+ $50 \%$ at tillering) gave the best result. Our results revealed that, biofertilizers with organic manure can be a better supplement of inorganic fertilizers to produced better growth and production of wheat.

\section{Acknowledgement}

The author thanks Rajasthan College of Agriculture, MPUAT, Udaipur for the help and support rendered in carrying out the field trial.

\section{References}

Ahemad, M. and Khan, M.S. 2009. Effect of insecticide-tolerant and plant growth promoting Mesorhizobium on the performance of chickpea grown in insecticide stressed alluvial soils. Journal of Crop Science and Biotechnology, 12: 213-222.

Arancon NQ, Edwards CA 2005. Effects of vermicomposts on plant growth. Paper presented during the International Symposium Workshop on Vermi Technologies for Developing Countries (ISWVT 2005), Los Banos, Philippines November 16-18.

Avivi, Y. and Feldman, M. 1982. The 
response of wheat to bacteria of genus Azospirillum. Israel Journal of Botany, 31: 237- 245.

Azarpour, E., Moradi, M. and Bozorgi, H.R. 2012. Effects of vermicompost application and seed inoculation with biological nitrogen fertilizer under different plant densities in soybean [Glycine $\max (\mathrm{L}$.$) cultivar, Williams].$ African Journal of Agricultural Research, 7(10): 1534-1541.

Bejbaruah, R., Sharma, R.C. and Banik, P. 2013. Split application of vermicompost to rice

(Oryza sativa L.): its effect on productivity, yield components and $\mathrm{N}$ dynamics. Organic Agriculture, 3(2):123-128.

Biri, A., Kaba, S., Taddesse, F., Dechassa, N., Sharma J.J., Zewidie, A. and Chavhan, A. 2016. Effect of vermicompost and nitrogen application on striga incidence, growth, and yield of sorghum [Sorghum bicolor (L.) Monech] in Fedis, Eastern Ethiopia. International Journal of Life Sciences, 4 (3): 349-360.

Donald, C. M. and Hamblin, J. (1976). The biological yield and harvest index of cereals as agronomic and plant breeding criteria. Advances in Agronomy, 28: 361-405.

Hadis, M., Meteke, G. and Haile, W. 2108. Response of bread wheat to integrated application of vermicompost and NPK fertilizers. African Journal of Agricultural Research, 13(1): 14-20.

Kaushik, M.K., Bishnoi, N.R. and Sumeriya, H.K. 2012. Productivity and economics of wheat as influenced by inorganic and organic sources of nutrients. Annals of Plant and Soil Research, 14(1): 61-64.

Khan, N.H., Ali, M.R.A., Saeed, M.A. 2013. Physiochemcial traits, productivity and net return of wheat as attached by phosphorus and zinc requirements under arid climates. Pakistan Journal of Botany, 43(2):991-1002.
Kheyri, N. 2017. Effect of rate and time of application of vermicompost on yield and yield components of rice (Oryza sativa L.). Applied Research in Field Crops, 30(2):91-110.

Kumar, A. 2013. Development of a liquid biofertilizer with indigenous microbial strains of Himachal Pradesh. Available on http://shodhganga.inflibnet.ac.in access on dated 27th October, 2014.

Kumawat, K. Patel, P.P., Dambiwal, D., Reddy, T.V. and Hakla, C.R. 2017. Effect of liquid and solid bio-fertilizers (Rhizobium and PSB) on growth attributes, yield and economics of fenugreek [Trigonella foenum graecum L.]. International Journal of Chemical Studies, 5(4): 239-242.

Parthasarathi, K., Balamurugan, M. and Ranganathan. L.S. 2007. Influence of vermicompost off the physicochemical and biological properties in different types of soil along with yield and quality of the pulse crop-Black Gram, 7 (1): 854-857.

Patra, B. and Singh, J. 2018. Effect of priming, biofertilizers and nitrogen levels on yield and nutrient uptake by wheat. International Journal of Current Microbiology and Applied Science, 7(07): 1411-1417.

Rao, S. and Sitaramaya, M. 2000. Performance of alternate organic nitrogen sources in an Inceptisol under rice. In: proceedings of international conference on managing natural resources for sustainable agriculture production in the 21 st century New Delhi, pp.1464-1465.

Sharma, R., Dahiya, S., Rathee, A., Singh, D., Nandal, J.K. and Malik, R.K. 2009. Effect of INM on growth, yield, economics and soil fertility in ricewheat cropping system, Indian Journal of Fertilizers, 5(3): 31-34.

Singh, Y.V., Dhar, D.W. and Agrawal, B. 
2011. Influence of organic nutrient management on basmati rice (Oryza sativa)-wheat (Triticum aestivum)greengram (Vigna radiata) cropping system. Indian Journal of Agronomy, 56 (3): 169-175.

Sinha, R.K., Valani, D., Chauhan, K. and Agarwal, S. 2014. Embarking on a second green revolution for sustainable agriculture by vermiculture biotechnology using earthworms: reviving the dreams of Sir Charles Darwin. International Journal of Agric
Health Safty, 1: 50-64.

Uribe, D., Sánchez-Nieves, J., Vanegas, J. Role of Microbial Biofertilizers in the Development of a Sustainable Agriculture in the Tropics. In Soil Biology and Agriculture in the Tropics; Springer: Berlin, Germany, 2010.

Verma, S.R., Shivran, A.C., Bhanwaria and Singh, M. 2014. Effect of vermicompost and sulphur on growth, yield and nutrient uptake of fenugreek (Trigonella foenum graecum). The Bioscan, 9: 667670.

\section{How to cite this article:}

Sushila Aechra, R. H. Meena, Gajanand Jat, Jitendra Sharma, Kiran Doodhwal and Hemraj Jat. 2020. Effect of Biofertilizers and Split Application of Vermicompost on Productivity and Profitability of Wheat (Triticum aestivum L.) Crop in Clay Loam Soils. Int.J.Curr.Microbiol.App.Sci. 9(04): 1129-1139. doi: https://doi.org/10.20546/ijcmas.2020.904.134 